13. Leffler CW, Busija DW 1985 Arachidonate metabolism on the cerebral surface of newborn pigs. Prostaglandins 30:811-817

14. Kontos H 1985 Oxygen radicals in cerebral vascular injury. Circ Res 57:508516

15. Busija DW, Leffler CW 1989 Cerebrovascular consequences of intracranial blood in piglets. Fed Proc 3:A1166(abstr)

16. Busija DW, Leffler CW 1990 Perivascular blood attenuates noradrenergic but not cholinergic effects on piglet pial arteriole. Stroke 21:441-446

17. Leffler CW, Busija DW, Armstead WM, Mirro R, Beasley DG 1983 Ischemia alters cerebral vascular responses to hypercapnia and acetylcholine in piglets. Pediatr Res 25:180-183

18. Leffler CW, Beasley DG, Busija DW 1984 Cerebral ischemia alters cerebral microvascular reactivity in newborn pigs. Am J Physiol 257:H266-H271

19. Leffler CW, Busija DW, Beasley DG, Armstead WM, Mirro R 1989 Postischemic cerebral responses to norepinephrine and hypotension in newborn pigs. Stroke 20:541-546

20. Pourcyrous M, Leffler CW, Busija DW 1990 Role of prostanoids in cerebro- vascular responses to asphyxia and reventilation in newborn pigs. Am J Physiol 259(in press)

21. Clark GD, Rathnear SM 1987 Blockade of excitatory amino acid receptors protects anoxic hippocampal slices. Neuroscience 21:665-671

22. Kukreja RC, Kontos HA, Hess ML, Ellis EF 1986 PGH synthase and lipooxygenase generate superoxide in the presence of NADM or NADPH. Circ Res 59:612-619

23. Yoshida S, Abe K, Busto R, Watson BD, Kogura K, Ginsbery MD 1982 Influence of transient ischemia on lipid-soluble antioxidants, free fatty acids, and energy metabolites in rat brain. Brain Res 245:307-316

24. Pourcyrous M, Leffler CW, Busija DW 1988 Post-asphyxial increases in prostaglandins in cerebrospinal fluid in piglets. Pediatr Res 24:229-232

25. Imaizumi S, Kayman T, Suzuki J 1984 Chemiluminescence in hypoxic brainThe first report correlation between energy metabolism and free radical reaction. Stroke 15:1061-1065

26. Ment LR, Stewart WB, Duncan CC 1985 Beagle puppy model of intraventricular hemorrhage: effect of superoxide dismutures on cerebral blood flow and prostaglandins. J Neurosurg 62:563-569

\title{
Announcement
}

\section{New Pregnancy Education Book Offered}

A new pregnancy educational booklet, Pregnancy Nutrition and You, has been introduced by Carnation Company to provide accurate, up-to-date information to mothers. Professionals who would like to receive a complimentary book as well as ordering instructions for additional copies of the book can submit their request on professional letterhead to: Carnation Company, P.O. Box 200, Pico Rivera, CA 90665. Additional copies require a nominal fee to cover shipping and handling. 